\title{
NEW AND LITTLE-KNOWN CALYPTRATE DIPTERA FROM NEW ENGLAND.
}

\author{
By J. R. Malloch.
}

Biological Survey, Washington, D. C.

The first three species belong to the family Scatophagidæ, the others to the Muscidæ (=Anthomyiidæ auct.).

\section{Microprosopa flavinervis sp. nov.}

Male--Head yellow, interfrontalia more rufous; ocellar triangle and upper half of occiput fuscous, gray pruinescent; second antennal segment and arista yellow, third antennal segment black; palpi whitish yellow; vibrissæ and genal bristles luteous; orbital, vertical, and ocellar bristles black. Thorax black, densely gray pruinescent. Abdomen tawny, fuscous dorsally on basal half. Legs, including coxæ, yellow. Wings yellowish, veins yellow. Halteres yellow.

Upper three orbital bristles nearer eye than lower three, the second and third curved forward and outward, the lower three incurved; arista almost bare; vibrissæ duplicated; eye a little longer than high, slightly pear-shaped, the narrow extremity in front. Dorsocentral bristles rather short, two pairs in front of suture; scutellum with four equal bristles. First and fourth visible tergites longer than second and third, fifth a little longer than fourth, not extending to margin on left side; sixth tergite as long as fifth; hypopygium large, occupying nearly half of length of venter; processes of fifth sternite robust, obtusely pointed. Fore and mid tibiae each with a fine median anterodorsal bristle; hind femur without distinct anteroventral bristles; hind tibia with one posterodorsal and one or two anterodorsal bristles.

Length, $5 \mathrm{~mm}$.

Type and paratype, Auburndale, Mass., May. 


\section{Orthochaeta dissimilis sp. nov.}

Male and female.-Black, shining, thorax and abdomen with distinct gray pruinescence, most dense on pleura. Head black, face and anterior portion of interfrontalia reddish; face, frons, and cheeks with white pruinescence; antennæ and proboscis black; palpi yellow. Thoracic dorsum rather indistinctly trivittate. Abdomen black or yellowish brown. Legs yellow, coxæ slightly brownish at bases. Wings clear, more yellowish basally, veins yellow. Calyptræ white. Halteres yellow.

Frons slightly over one third of the head width, narrowed anteriorly; each orbit with about eight bristles; antennæ nearly as long as face, third segment broad, its apex with an acute upper angle; arista nearly bare, second segment in male about twice as long as thick, third very much swollen at base, rapidly becoming slender apically; arista of female with second segment shorter than in male, the third swollen on its basal third; cheek not over one tenth as high as eye, with about six long marginal bristles; vibrisse long, one bristle above it; proboscis slendee Thorax with the same bristles as the genotype, except that there are but two scutellars present. Fifth abdominal sternite of male with two long processes which are slightly tapered apically, their tips rounded. Fore femur with several bristles in a series on anterodorsal surface, the one nearest apex much stronger than the others; fore tibia with one posteroventral, two posterodorsal, and two anterodorsal bristles; mid and hind femora each with several widely spaced bristles on anterodorsal, anteroventral, and posteroventral surfaces; mid tibia with the following bristles: one anteroventral, two anterodorsal, two posterodorsal, and one posterior; hind tibia with one anteroventral, three posterodorsal and three anterodorsal bristles. Costa with short black spinules; last section of veins 3 and 4 nearly parallel.

Length, $7.5-8.5 \mathrm{~mm}$.

Type, Algonquin, Ill., June 3, 1898. Paratypes, Urbana, Ill., May 7, 1907; Great Falls, Va., May 10, 1915; Norfolk, Ct., May 21, 1916; Columbus, Ohio, May 7, 1902; and four specimens from the Osten Sacken Collection in the Museum of Comparative Zoology, taken in 1874, without legible locality labels. 
Scatophaga monticola sp. nov.

Male.-Similar to furcata Say in color, the third antennal segment fuscous, palpi yellow; dorsum of thorax with four pale brown vittæ; apices of abdominal tergites narrowly black; legs yellow, fore femora with a darker stripe on posterodorsal surface; wing veins clouded, the apices of veins 2,3 , and 4 rather faintly so, both cross-veins with spot-like clouds.

Arista bare; palpi dilated. Thorax with $2+3$ dorsocentral bristles which are very distinct because of their strength and the scarcity of dorsal hairs; pteropleura and hypopleura bare. Processes of fifth sternite long, tapered to a rounded point, their basal width less than half as great as their length, no short spines evident. All femora and tibiæ with rather dense erect ventral hairs the length of which does not noticeably exceed the diameter of the parts upon which they are situated; fore tibia with two anterodorsal and one fine posterior bristle: mid and hind femora without distinct ventral bristles; mid tibia with two or three anterodorsal and posterodorsal bristles; hind tibia with three anterodorsal and posterodorsal bristles, the anteroventral bristles usually indistinguishable.

Female.-Similar to the male in color but slightly darker. Abdomen pointed. Legs less hairy, the hind femora usually with one or two anteroventral bristles apically.

Length, $7 \mathrm{~mm}$.

Type, male, allotype, and one female paratype, Mt. Washington, N. H.

The fifth sternite in male is similar to Figure 22, pl. 14, in my paper on the Pribilof Island Diptera ${ }^{1}$, which is unfortunately mislabeled furcata instead of islandica and so referred to in the text. Figure 21 represents the fifth sternite in furcata.

The description herein presented is drawn from specimens in the U. S. National Museum collected by Mrs. A. T. Slosson and labeled S. bicolor Walker. I am confident that Walker's species is a synonym of furcata Say. These specimens were brought to my attention by Dr. J. M. Aldrich. The bare arista,

${ }^{1}$ North Amer. Fauna, No. 46, U. S. Dept. of Agriı, Biol. Surv. 1923. 
pteropleura, and hypopleura distinguish the species from its allies.

\section{Hylemyia sinuata sp. nov.}

Male.-Black, shining, thorax uniformly gray pruinescent, abdomen with gray pruinescence on sides of tergites, the dorsocentral black vitta very broad. Legs black. Wings hyaline, fuscous at extreme bases, veins black. Calyptræ whitish. Halteres yellow.

Eyes separated by a little more than width across posterior ocelli; orbits narrow, setulose to above middle; interfrontalia with one or two pairs of cruciate bristles; parafacial at base of antennæ wider than third antennal segment, much narrowed below; cheek about as high as greatest width of parafacial, with a single series of bristles below; third antennal segment about 1.5 as long as second; arista subnude; proboscis normal. Presutural acrostichals uniserial, sparse, long; prealar over half as long as the bristle behind it; sternopleurals 1:2. Abdomen short and stout, hypopygium rather large; processes of fifth sternite long and slender, their length along inner margin as great as that of basal two segments of hind tarsus, the inner margin of each sinuate and furnished at middle with a fringe of dense, short, stiff hairs, apex on inner side with a few short, fine hairs, the outer margin with some long bristles. Fore tiabi with an anterodorsal and a posterior bristle; fore tarsus as long as tibia; mid femur with a few bristles on basal half of anteroventral and posteroventral surfaces; mid tibia with two anteroventral, anterodorsal, posterodorsal, and posteroventral bristles; hind femur with a complete series of anteroventral, and some shorter posteroventral bristles on basal half; hind tibia with three or four anteroventral, anterodorsal, and posterodorsal bristles, and a few posterior setulæ. Outer cross-vein of wing almost straight.

Length, $4 \mathrm{~mm}$.

Type, Newton, Mass., May 15, 1920 (C. W. Johnson).

The peculiar processes of fifth sternite separate this species from any other in the genus known to me. 
Hylemyia longipalpis sp. nov.

Male-Black, slightly shining, densely gray pruinescent, the abdomen with a slight bluish tinge. Anterior margin of frons and of parafacials reddish; orbits, parafacials, face, and cheeks with silvery pruinescence; antennæ and palpi black. Thorax indistinctly vittate. Abdomen with a black dorsocentral vitta which is dilated at anterior and posterior margin of each segment. Legs black. Wings hyaline. Calyptræ white. Halteres brownish yellow.

Eyes separated by about the distance between posterior ocelli; orbits almost obliterating interfrontalia in front of ocelli; orbital bristles extending to middle interfrontalia with a weak pair of cruciate bristles; parafacials at base of antennæ as wide as third antennal segment; slightly narrowed below; cheek as high as widest part of parafacial, armed as in flavifrons; third antennal : gement on inner side subequal in length to second; arista swollen on basal fourth, almost bare; palpi longer than usual, slightly spatulate at apices. Thoracic dorsum with sparse, erect, long hairs; three pairs of acrostichals in front of suture; prealar about one third as long as the bristle behind it; sternopleurals 1:2. Abdomen depressed, narrow, the segments subequal; seventh tergite (fifth visible) with numerous long fine bristles; fifth sternite with the processes short, glossy and almost bare at apices. Fore tibia with several fine setulose hairs on posterior surface, the apical posterior bristle minute; fore tarsi compressed, as long as tibia; mid femur with a series of strong bristles on basal half of anteroventral and posteroventral surfaces and another series above the latter; mid tibia with two posterodorsal and posterior bristles; hind femur with very long bristles, which are rather closely placed, on anteroventral and posteroventral surfaces, the latter not extending to apex; hind tibia with three long bristles on posterodorsal surface, about 8 or 9 short anterodorsal and anteroventral setulæ, and some hairs on middle of posterior surface. Costal thorn minute.

Female.-Differs from the male in having the head with brownish pruinescence, the interfrontalia reddish, and the abdomen unmarked. 
The frons is one third of the head-width, the cruciate interfrontals are long, the palpi more noticeably spatulate, and the legs much less bristly.

Length, 3.5-4 mm.

Type, male, and allotype, Waterville, Me., May 11, 1906.

(Hitchings).

The male of this species is distinguished from any in the genus known to me by the form of the processes of fifth sternite, armature of fore tibia, hind tibia, and mid and hind femora.

It bears a resemblance to bicaudata Malloch in some characters but is easily separated by the femoral bristling.

Caly thea Schnabl and Dzeidzicki

This genus I distinguished from Anthomyia by the presence of fine hairs on the upper margin of the hypopleura in front of the spiracle, but I find that in most of the European specimens of the genotype there are no hairs present and when there are any they are very sparse and difficult to distinguish. My statement was based upon an examination of specimens which had either been named by Stein or compared with those so named. Just recently I have had some European specimens given to me and after an exhaustive examination of these desire to amend the generic definition as follows: Hypopleura usually with some fine hairs on upper margin in front of spiracle, absent only in albicincta Fallen, and with some similar hairs at lower posterior angle; prosternum always with some fine marginal hairs; hind tibia with one long posterodorsal bristle beyond middle; lower calyptra protruded; propleura bare below humeral angle, but with a dense tuft of setulose hairs above fore coxa; scutellum with fine hairs below.

Calythea separata sp. nov.

Male.-Similar to albicincta Fallen in general color and habitus. Differs in having no fuscous spot surrounding the posterior notopleural bristle, the anterior margin of thoracic dorsum less obviously grayish, the gray stripes on posterior 
third of mesonotum much broader, that on line of intra-alar bristles more elongate, and the apex of scutellum more broadly gray.

Structurally this species differs from all others of the genus in having the antennæ separated at bases by a very noticeable rounded carina which is distinctly shining on upper part, and the epistome is much more produced, the anterior margin being almost in line with anterior margin of third antennal segment. Eyes subnude; arista almost bare. Hind femur usually with but two posteroventral bristles, one at base and the other near middle; posterodorsal bristle on hind tibia rather short.

Length, 3-4 mm.

Type, Buttonwoods, R. I., July 25, 1911. Paratype, Tiverton, R. I., July 31; Woodbury, N. J., June 27, 1896; Eastham, Mass., June 21, 1908 (C. W. Johnson); Potomac Run, Va., May 30, 1916, on Chrysanthemum leucanthemum; Chesapeake Beach, Md., September 19, 1915; Beltsville, Md., August 8, 1915 (W. L. McAtee); Denton, Texas, April 27 (C. R. Jones).

Stein has placed micropteryx Thomson, anthracina Bigot, and monticola Bigot as synonyms of albicincta Fallen and suggests the same relationship for bidentata Malloch. I have yet to see an authentic North American specimen of albicintca, my records and most if not all of those of Stein having reference to micropteryx Thomson, judging from what I know of the distribution of this species, which was described from California. It is highly probable that both the Bigot species are synonyms of this species also, but only an examination of the types will determine this. I have again examined the type of bidentata and consider that it is distinct from the other species, having a larger velvety brownish black frontal triangle, the orbits with denser bristles, the profile of the head different, and the dorsum of thorax and abdomen deep black, with only a very short whitish triangle on each side of the median line of each abdominal tergite. We have thus apparently three distinct species in North America, and from an examination of material which I was permitted to make in the U. S. National Museum by Dr. Aldrich I believe we have probably two others in South America and Mexico. 


\section{Spilogona Schnabl.}

Spilogona will supplant Melanochelia Rondani as the generic name for the group dealt with under the last name in my paper in Canadian Entomologist, pages 61-64, 1921.

\section{Spilogona argenticeps sp. nov.}

Male.-Head black, entire frons, face, and cheeks densely white dusted, the two latter almost tomentose and silvery, back of head pale gray pruinescent. Thorax pale gray pruinescent, with three very faint dark vittæ; scutellum darker, more shining, and when seen from in front with the sides darker than the disc. Abdomen whitish gray pruinescent, first tergite largely black on disc, the next three each with a pair of large subtriangular black spots which extend almost the entire length of tergites and are distinctly separated in middle. Legs pitchy colored. Wings slightly grayish, veins brown, whitish at bases. Clyptræ white. Halteres yellowish white.

Frons a little less than one third of the head width, orbits not strikingly differentiated, narrowed posteriorally; ocellar bristles long; antennæ slender, third segment twice as long as second, its apex about one third from lower margin of face; arista pubescent; parafacial as wide as, cheek twice as high as width of third antennal segment; vibrissæ long; eyes much higher than long. Thorax with three pairs of postsutural dorsocentral bristles, the fine hairs very short and sparse; lower sternopleural bristle very weak. Abdomen narrowly ovate; hypopygium small, forceps much drawn out at apices (Fig. 1); fifth sternite, not visible in type. Legs slender; fore tibia without a median posterior bristle; middle legs missing in type; hind femur with two or three fine setulæ near apex on antero-ventral surface, only one of these bristle-like; hind tibia with one anteroventral and two anterodorsal setulæ. Veins 3 and 4 slightly divergent at apices; outer cross-vein at a little less than its own length from apex of fifth vein; penultimate section of fourth vein less than half as long as ultimate section.

Length, $4 \mathrm{~mm}$.

Type, Mt. Washington, N. H., August 8, 4000 feet. 
This species is most nearly related to caroli Malloch to which it will run in my published key to the species already referred to. That species differs, however, in having the frons wider and, except for the orbits, black instead of white, the orbits with more numerous and stronger bristles, the legs stronger, and the fore tibia with a fine median posterior bristle.

The European species pollinifrons Stein, like caroli, has the cheek not higher than width of third antennal segment, and though the frons is white there is no anteroventral bristle on the hind femur, the last character being used as diagnostic in Stein's key to the European species.

\section{Spilogona alticola Malloch.}

This species is remarkably close to contractifrons Zetterstedt, to which it runs in all the keys to the European species which I have seen. To make certain of the specific status of the species I have dissected the male genitalia of both and present figures herein to illustrate their distinctions (Figs. 2 and 3). It is almost impossible to separate the species by the use of external characters. Staeger and Lundbeck have recorded contractifrons from Greenland but the records are probably erroneous.

Stein has recorded the closely related European species baltica Ringdahl as occurring in North America. The record should be confirmed by a comparison of the male genitalia of specimens from these continents before acceptance.

\section{Spilogona novæ-angliæ Malloch}

This species is very closely related to brunneisquama Zetterstedt (armipes Stein) which has been recorded from Washington State by Stein. I have dissected male specimens of both species and present figures of the hypopygia to show the specific distinctions (Figs. 4 and 5). Externally the species are almost the same and it is possible that Stein had nover-anglice and not brunnesisquama before him; an examination of his specimen is necessary to decide this, however. 


\section{Spilogona acuticornis Malloch.}

This species is very closely related to $\operatorname{surda}$ Zetterstedt. It has, however, a distinct dorsocentral vitta between the spots on abdomen which is absent in surda, the frons is as wide as eye at middle as seen from in front, the apex of each process of fifth abdominal sternite is much more produced, and though, like surda, it has fine long bristly hairs on basal half of posteroventral surface of hind femur these are more numerous than in the latter and not in a single series. The crossveins of the wing are more widely separated than in surda.

One male, Machias, Me., July 17, 1909.

These notes are drawn from a comparison of the above specimen and an authentic male of surda sent to me along with brunneisquama and contractifrons by Mr. O. Ringdahl from Sweden.

\section{Neohydrotæa, gen. nov.}

Generic characters: Male.---Eyes bare, barrowly separated; arista distinctly pubescent on basal half; cheek narrow, with many marginal bristles, and 1 strong upwardly curved bristle about one third from anterior extremity. Prealar bristle strong, over half as long as the one behind it; sternopleura with lower posterior bristle distinct, but not nearly as long as the upper; hypopleura and pteropleura bare. Fore femora with a flattened, slightly excavated area at apex on ventral surface, basad of which on the antero-ventral surface the bristles are short and stout, no stout thorn present. In other respects as Hydrotæa.

Genotype, the following species.

Neohydrotæa hirtipes, sp. nov.

Male.-Black, shining. Head black, face and orbits with silvery pruinescence; antennæ black, third joint reddish at base on inner side; palpi brown. Thoracic dorsum with whitish pruinescence, most distinct, in the form of a broad vitta, on acrostichal area; viewed from behind the dorsum has a quadri- 
vittate appearance. Abdomen with a slender black dorso-central stripe and very faint dark checkering, the surface with yellowish gray pruinescence. Legs yellow, fore coxæ brownish, mid and hind coxæ brownish, all trochanters, and the tarsi fuscous. Wings yellowish, noticeably so basally. Calyptra and halteres yellow.

Eyes at narrowest part of frons separated by a little more than width across posterior ocelli; antennæ not extending to lower margin of face, third joint twice as long as second; cheek about one eighth as high as eye. One pair of long widely separated acrostichals just in front of suture, the remainder of acrostichal area proximad of suture with 6 to 8 series of setulose hairs; 3 pairs of post-sutural dorsocentrals. Abdomen elongate ovate; fifth sternite with a groad rounded posterior excision, the lateral extremities slightly recurved ventrad as in Hydrotæa; hypopygium retracted, glossy black. Fore femur with a series of stout bristles on postero-ventral surface which is duplicated beyond middle, and on apical third the bristles become longer, more slender, and dense; antero-ventral surface with very short bristles up to beginning of the preapical excavation; fore tibia with black shaggy hairs on the entire length of posteroventral surface, which are most dense near base; mid femur with several very long bristles on basal half of anterior surface; the ventral surface with a few widely placed bristles; mid tibia with three posterior bristles; hind femur with 5 or 6 long bristles on apical fourth of antero-ventral surface; hind tibia with apical half of ventral surface furnished with dense black hairs which are longer and bristly on antero-ventral surface; antero-dorsal surface with short hairs and 2 or 3 weak bristles; postero-dorsal surface with 2 or 3 bristles, the upper one straight; apex of tibia with 2 or 3 bristles, one of which on ventral surface is long and curved; tarsi long and slender. Outer cross-vein oblique, curved; veins 3 and 4 convergent apically.

Length, $8 \mathrm{~mm}$.

Type locality, Chester, Mass., July 25, 1913 (C. W. Johnson).

The only allied North American species which has yellow legs is succedens Stein, but this has the prealar bristle absent and the abdomen largely yellow. $H$. succedens appears to be a true Hydrotæa. 
The type has a weak setulose hair near base of auxiliary vein on right wing and a similar setula on first vein near the same place on left wing. These setulæ are evidently abnormal and are not given in the description as either generic or specific characters.

\section{Explanation of Plate IX.}

Hypopygial Characters of Males of Spilogona.

Fig. 1, argenticeps, apex of superior hypopygial claspers.

" 2, alticola, a, fifth sternite; b, left half of hypopygium; $c$, lateral view of internal parts of hypopygium; $d$, cephalic view of base of apical parts of same.

" 3, contractifrons, same as above.

" 4, nove-anglice, a, fifth sternite; b, hypopygium from behind, c, lateral view of internal parts of hypopygium; $d$, front view of left half of last.

$" 5$, brunneisquama, letters same as in above but b shows apex only of superior hypopygial claspers. 
Psyche, 1924.

VOL. 3I, PLATE IX.

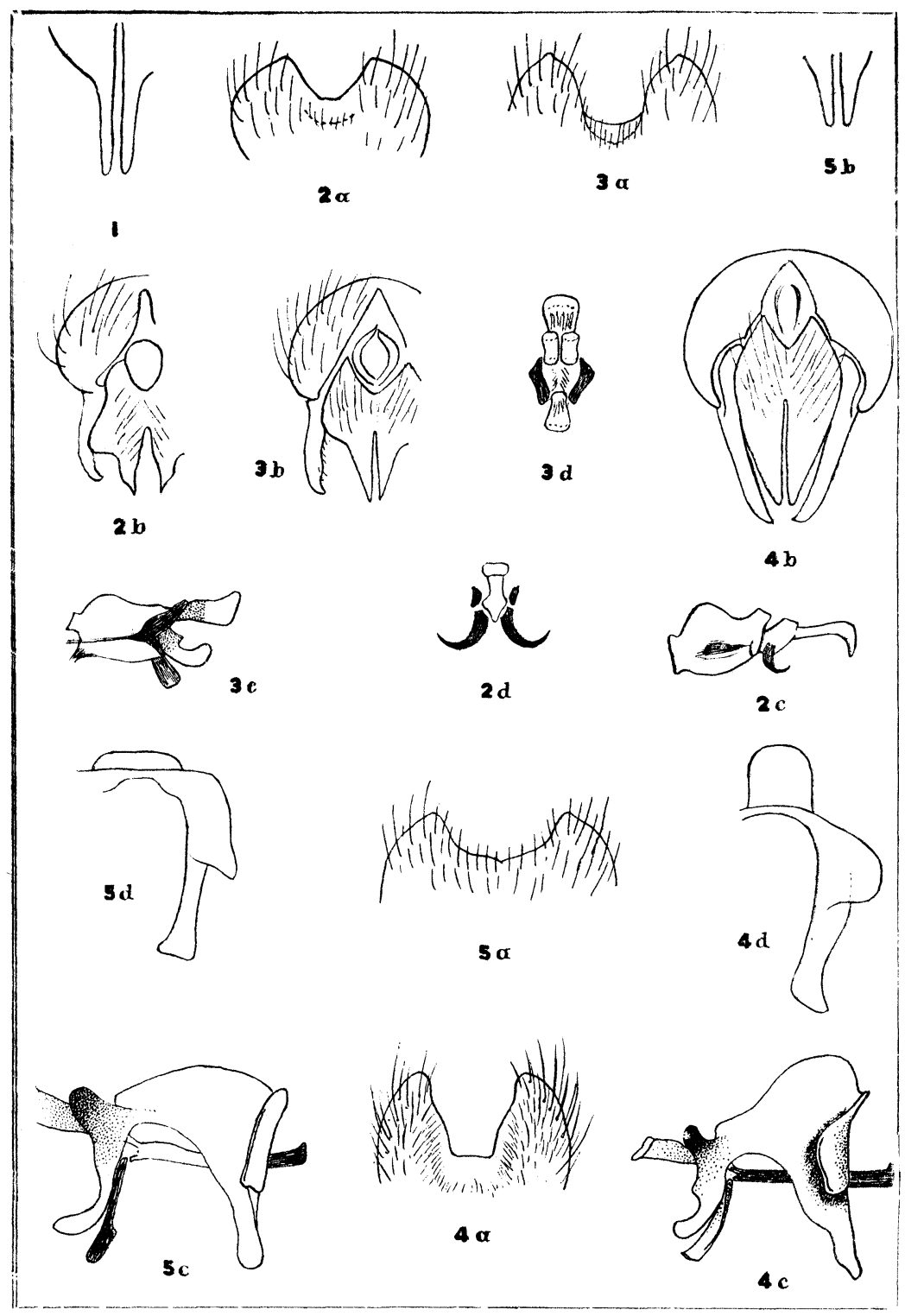

Malloch-Hypopygial Characters of Spilogona. 

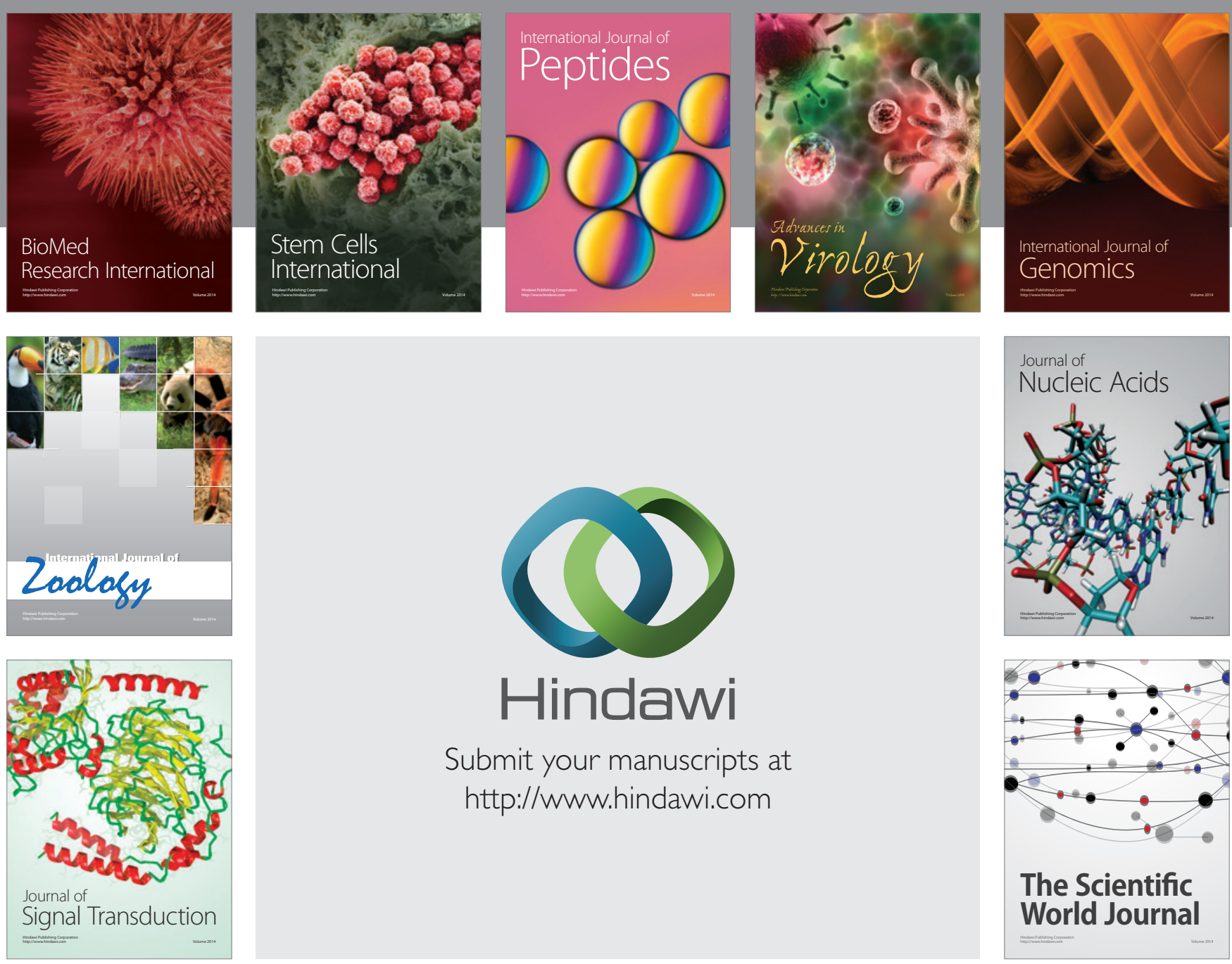

Submit your manuscripts at

http://www.hindawi.com
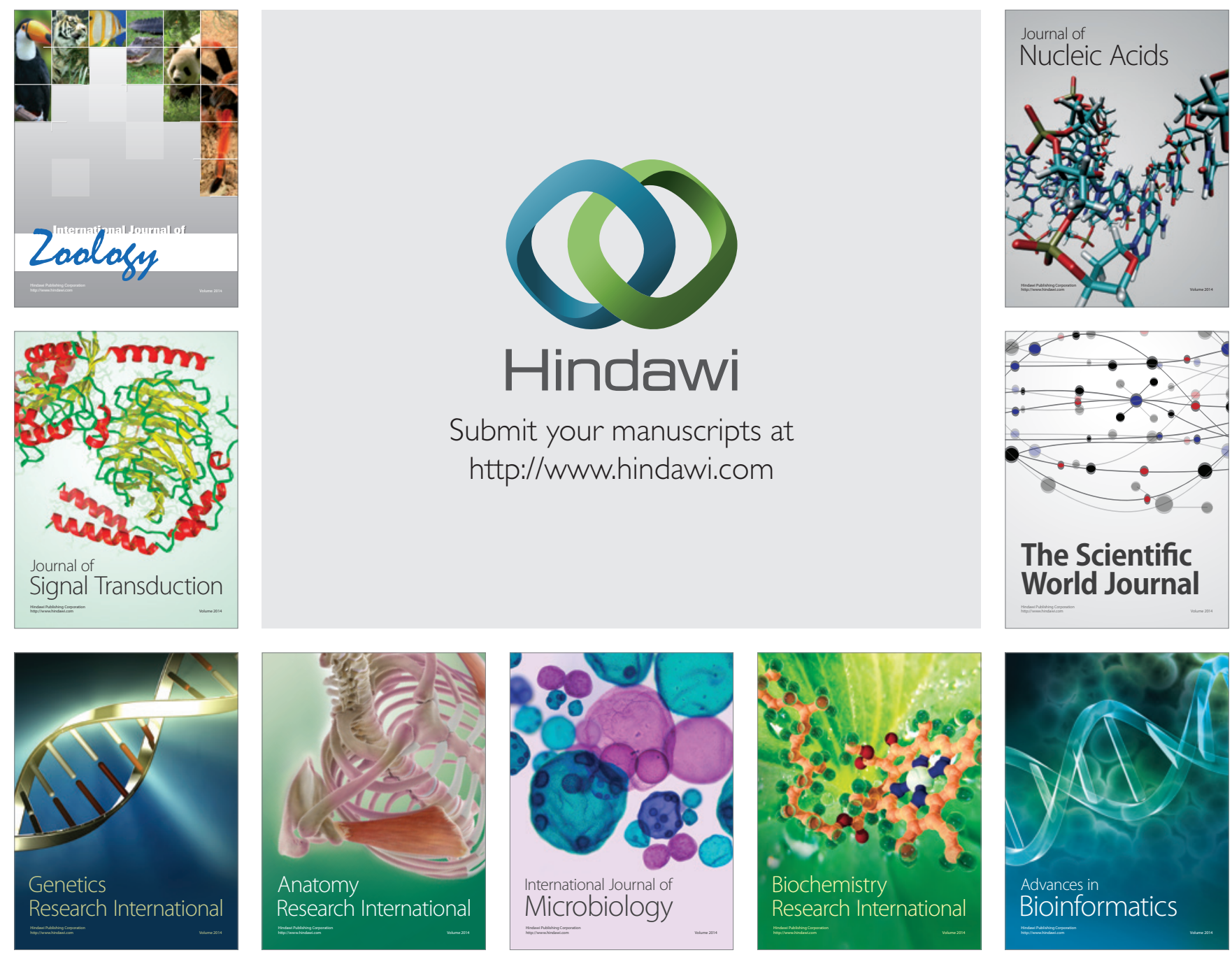

The Scientific World Journal
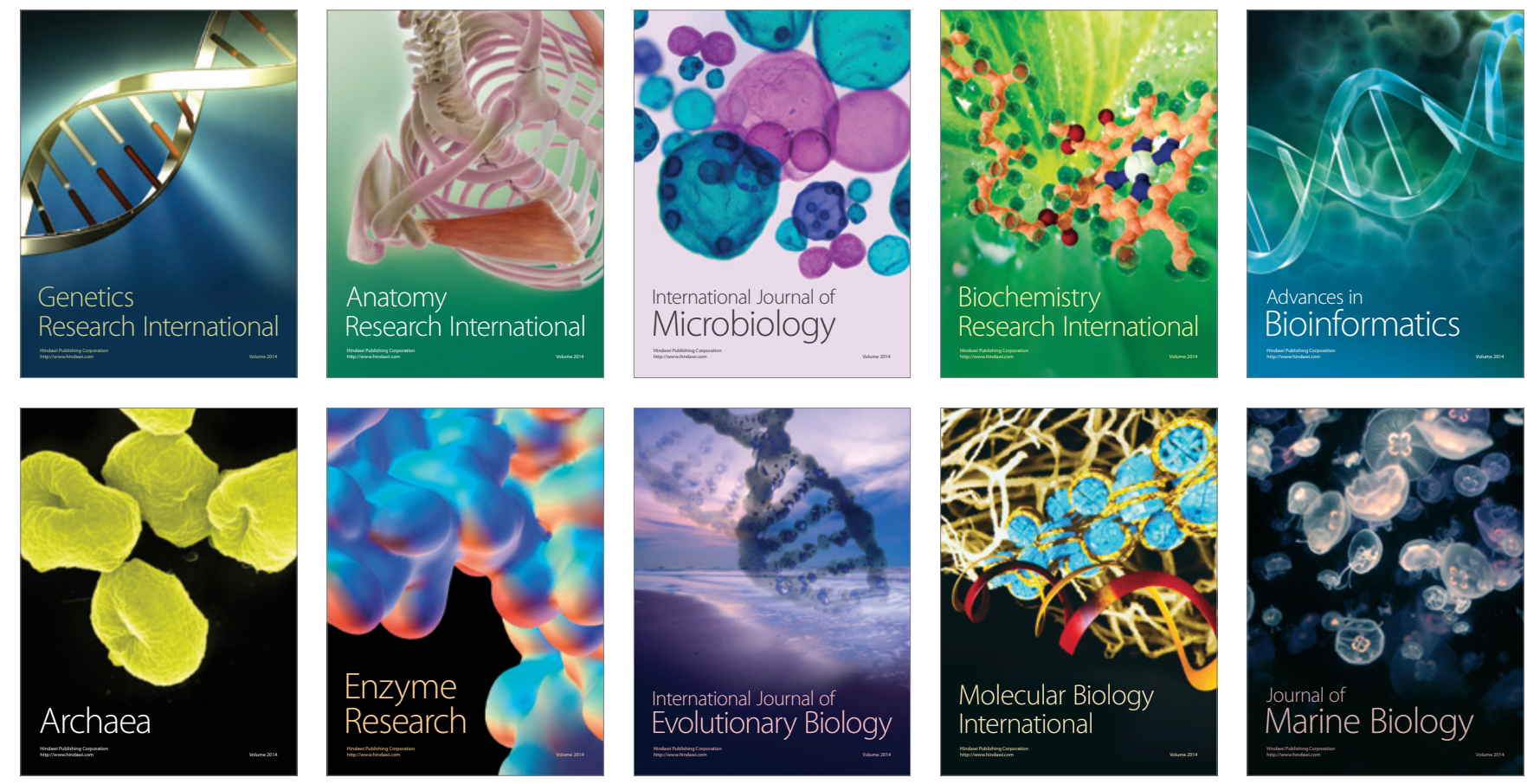